\title{
Pengaruh Model Creative Problem Solving (CPS) Berbantuan Video Pembelajaran Terhadap Kemampuan Pemecahan Masalah Ditinjau Dari Minat
}

\author{
Wayan Partayasa ${ }^{1 *}$, I Gusti Putu Suharta ${ }^{2}$, I Nengah Suparta ${ }^{3}$ \\ 1,2,3Program Magister Pendidikan Matematika, Universitas Pendidikan Ganesha, Singaraja, \\ Indonesia, ${ }^{1, *}$ wayanpartayasaa@gmail.com; 2igpsuharta@yahoo.com; \\ 3nengah.suparta@undiksha.ac.id
}

Info Artikel: Dikirim: 10 Oktober 2019; Direvisi: 29 Januari 2020; Diterima: 27 Februari 2020 Cara sitasi: Partayasa, W., Suharta, I. G. P., \& Suparta, I. N. (2020). Pengaruh Model Creative Problem Solving (CPS) Berbantuan Video Pembelajaran Terhadap Kemampuan Pemecahan Masalah Ditinjau Dari Minat. JNPM (Jurnal Nasional Pendidikan Matematika), 4(1), 168-179.

\begin{abstract}
Abstrak. Tujuan penelitian ini untuk mengetahui kemampuan pemecahan masalah matematika dan minat belajar siswa yang mengikuti model Creative Problem Solving (CPS) berbantuan video pembelajaran. Penelitian ini menggunakan pendekatan kuantitatif dan kualitatif dengan desain sequential explanatory. Analisis data kuantitatif menggunakan uji-t dan data kulitatif menggunakan analisis deskriptif. Data kuantitatif diperoleh melalui post test sedangkan kualitatif dari hasil observasi, wawancara, angket minat belajar siswa, dan dokumentasi. Sampel sebanyak 54 siswa dari keseluruhan kelas VII SMPN 1 Lunyuk. Pengambilan sampel dilakukan dengan teknik cluster random sampling. Hasil penelitian menunjukan bahwa kemampuan pemecahan masalah metematika siswa yang mengikuti model CPS berbantuan video pembelajaran lebih baik daripada pembelajaran konvensional. Selanjutnya, untuk siswa yang memiliki minat belajar lebih tinggi maupun yang lebih rendah, penerapan model CPS berbantuan video pembelajaran lebih baik dari pada pembelajaran konvensional. Sehingga, model CPS berbantuan video pembelajaran berkontribusi positif terhadap kemampuan pemecahan masalah matematika siswa.
\end{abstract}

Kata kunci: Model CPS Berbantuan Video Pembelajaran, Kemampuan Pemecahan Masalah, Minat Belajar Siswa.

Abstract. The purpose of this study was to determine the ability of mathematical problem solving and learning interests of students who followed the Creative Problem Solving (CPS) model assisted by learning videos. This research used quantitative and qualitative approaches with sequential explanatory design. Quantitative data analysis used a $t$-test, and qualitative data used descriptive analysis. Quantitative data were obtained through a posttest while qualitative were the results of observations, interviews, student interest questionnaires, and documentation. The sample was 54 students from all eight grades of one of Junior High School in Lunyuk. Sampling was done by cluster random sampling technique. The results showed that the students' mathematical problem-solving ability who 
followed the CPS model assisted with video learning was better than conventional learning. Furthermore, for students who had a higher or lower interest in learning, the application of the CPS model assisted with video learning is better than conventional learning. So, the CPS model assisted with video learning positively contributes to students' mathematical problemsolving abilities.

Keywords: CPS Model Assisted by Video Learning, Problem-solving ability, and Student interest in mathematics learning.

\section{Pendahuluan}

Matematika memiliki peran yang sangat penting dalam pendidikan sebagai dasar dari ilmu pengetahuan yang digunakan secara luas dalam berbagai bidang kehidupan. Susanto (2013) menyatakan matematika adalah salah satu bidang studi yang bertujuan untuk menyelesaikan masalah yang berkaitan dengan hitung-menghitung atau dengan urusan angka-angka yang memerlukan suatu keterampilan dan kemampuan memecahkanya. Sehingga, siswa sebagai salah satu komponen penting dalam pendidikan harus selalu dilatih dan dibiasakan berpikir mandiri untuk memecahkan masalah. Pemecahan masalah adalah suatu proses penerapan pengetahuan (knowledge) yang telah dimiliki sebelumnya kedalam situasi yang baru (Susanto, 2013). Pentingnya pemecahan masalah matematika terletak pada tujuan dan hasil proses belajar dan mengajar, karena pemecahan masalah dianggap sebagai cara yang tepat untuk mempraktikkan pemikiran secara umum, atau dapat dikatakan bahwa tidak ada matematika tanpa berpikir, dan tidak ada pemikiran tanpa masalah (Aljaberi \& Gheith, 2016).

Namun, kemampuan siswa Indonesia masih relatif rendah dalam menyelesaikan soal cerita yang berkaitan dengan matematika khususnya soal non rutin, hal ini disebabkan karena siswa masih lemah dalam memahami masalah dan merencanakan penyelesaiannya. Berdasarkan hasil survei PISA yang dilakukan pada tahun 2015 ditemukan bahwa dari 70 negara yang berpartisipasi, Indonesia berada pada peringkat 63 dalam hal kemampuan matematika, kalah jauh dibanding Vietnam yang menduduki peringkat 12 dan Singapura yang berada pada peringkat pertama (OECD, 2016). Ng, P. T. (2017) menyatakan siswa di Singapura adalah problem solver terbaik.

Rendahnya kemampuan siswa dalam menyelesaikan masalah matematika, dikarenakan dalam proses pembelajaran tidak membiasakan siswa untuk berpikir dengan lebih kreatif. Rostika \& Junita (2017) menyatakan guru biasanya memberikan rumus cepat agar siswa mampu menyelesaikan soal yang bersifat konsep, bukan soal yang bersifat pemecahan masalah. Siswa cenderung memilih rumus atau cara cepat yang sudah biasa digunakan 
dibandingkan dengan langkah prosedural untuk menyelesaikan masalah matematika (Rofiqoh, 2015). Siswa mengerjakan soal setelah diberi contoh dengan soal yang diberikan hampir sama bentuknya dengan contoh yang membuat siswa hanya berfokus pada contoh (Purwati, 2015). Sehingga siswa kurang terampil (kesulitan) dalam menyelesaikan soal pemecahan masalah dan mengaplikasikan konsep yang telah dipelajari kedalam kehidupan nyata (Herlambang, 2013). Kesulitan tersebut akibat kurangnya kemampuan mengidentifikasi dan memahami masalah yang menyebabkan siswa gagal dalam memodelkan soal yang diberikan kedalam bentuk matematika. Ketika siswa gagal dalam memodelkan soal, maka bisa dibayangkan bagaimana siswa akan menemukan solusinya. Padahal, kemampuan mengidentifikasi dan memahami masalah merupakan langkah awal yang harus dilakukan sebelum menyusun strategi dan menerapkanya untuk memperoleh solusi.

Mengingat pentingnya kemampuan pemecahan masalah matematika, maka pembelajaran matematika dalam setiap kesempatan hendaknya dimulai dengan pengenalan masalah yang sesuai dengan situasi (contextual problem), yang mana siswa akan dibimbing secara bertahap untuk menguasai konsep matematika (Pujiadi, 2008). Sejalan dengan kurikulum 2013 yang merupakan kurikulum berbasis proses pembelajaran dengan mengedepankan pengalaman personal melalui melalui proses mengamati, menanya, menalar, dan mencoba untuk dapat meningkatkan kreativitas peserta didik. Untuk itu, guru harus lebih kreatif lagi dalam mengembangkan proses pembelajaran dikelas dan lebih selektif dalam memilih model atau metode pembelajaran agar benar-benar sesuai dengan kebutuhan siswa. Karena, dalam proses belajar mengajar aktivitas siswa tidak cukup hanya dengan mendengarkan, mencatat, dan mengkopi langkah-langkah penyelesaian masalah seperti yang lazim dilakukan, melainkan aktivitas yang memungkinkan siswa untuk dapat berpikir kreatif dalam memahami konsep pemecahan masalah melalui pengalaman dimiliki sebelumnya (Pujiadi, 2008).

Melihat permasalahan tersebut pendidik perlu merencanakan pendekatan pembelajaran yang mampu memaksimalkan kretivitas berpikir siswa dalam merancang strategi penyelesaian masalah yang berkaiatan dengan materi matematika. Adapun salah satu model pembelajaran yang dapat diterapkan adalah Creative Problem Solving (CPS) yang merupakan suatu model pembelajaran yang mengarahkan siswa untuk mengidentifikasi masalah, menghasilkan ide, dan mengunakan penyelesaian masalah yang inovatif untuk memperoleh solusi dari permasalahan, dimana guru menyajikan beberapa penomena/permasalahan dalam kehidupan sehari-hari yang dapat 
mengundang rasa keingin tahuan siswa, memberikan kesempatan siswa untuk mengidentifikasi fenomena/masalah, memberikan pertanyaan untuk mengarahkan siswa menghasilkan ide serta menyusun strategi pemecahan masalah, dan siswa menerapkan strategi terbaik untuk memperoleh solusi.

Model pembelajaran CPS lebih dominan untuk mengintegrasikan dimensi kognitif dan afektif siswa dalam mencari arah penyelesaian yang ditempuh untuk menyelesaikan masalah. Artinya, siswa diberikan keleluasaan untuk berkreativitas menyelesaikan permasalahanya sendiri dengan cara yang dikehendaki (Huda, 2013). Dalam hal ini, guru hanya berperan sebagai fasilitator yang membimbing siswa agar arah-arah yang ditempuh siswa tidak keluar dari permasalahan. Model ini mengajak siswa untuk terbiasa berpikir kreatif melalui diskusi kelompok untuk mengembangkan ide-ide yang dimiliki pada saat memecahkan masalah matematika. Diskusi kelompok memberikan kesempatan kepada siswa untuk dapat berpikir secara mandiri dalam mengidentifikasi maksud dan tujuan masalah, mengumpulkan data dan mengobservasi masalah tersebut, menciptakan sebanyak mungkin gagasan terkait dengan masalah, memilih solusi yang paling sesuai, dan melakukan tindakan penyelesaian masalah. Seperti pendapat dari Rostika \& Junita (2017) menyatakan bahwa kemampuan pemecahan masalah matematis siswa dapat berkembang apabila terdapat interaktif atau bertukar pendapat dalam menyelesaikan soal pemecahan masalah. Hal ini dilakukan agar tidak hanya dengan cara menghafal, melainkan keterampilan siswa dalam menyelesaikan masalah harus dimulai dari proses mengidentifikasi masalah, mengasilkan ide, dan memilih metode penyelesaian yang paling mudah menurutnya (Febriatina, 2017).

Beberapa hasil penelitian pun menunjukan bahwa model CPS efektif digunakan dalam pembelajaran. Penelitian Purwati (2015) dinyatakan bahwa kemampuan pemecahan masalah matematika siswa dengan model CPS lebih baik dari pada kemampuan pemecahan masalah matematika siswa yang mengikuti pembelajaran konvensional. Tia, Dalifa, \& Noperman (2014) dalam penelitianya diperoleh model pembelajaran CPS dapat meningkatkan aktivitas pembelajaran dan hasil belajar siswa. Sakaningsih, Asri, Negara, \& Ke (2014) menyatakan bahwa terdapat perbedaan hasil belajar yang signifikan antara siswa yang dibelajarkan dengan model CPS berbasis reinforcement dengan siswa yang dibelajarkan dengan pembelajaran konvensional.

Pada kenyataannya model pembelajaran CPS membutuhkan waktu yang lebih lama untuk mempersiapkan siswa dibandingkan dengan pembelajaran 
yang biasanya diterapkan. Perbedaan level pemahaman dan kecerdasan siswa dalam menghadapi masalah, serta ketidaksiapan siswa untuk menghadapi masalah baru sering menjadi kendala dalam penerapan pembelajaran CPS.

Untuk mengatasi hal tersebut model pembelajaran CPS dikombinasikan dengan video pembelajaran yang diberikan kepada siswa sebelum proses pembelajaran berlangsung dengan tujuan agar siswa memiliki pengetahuan awal melalui video tersebut. Video yang digunakan adalah video yang memuat tentang materi aritmatika sosial yang akan dibahas secara garis besar dan contoh penyelesaian masalah berupa soal cerita sederhana untuk memberikan gambaran awal tentang kemungkinan strategi yang dapat diterapkan untuk memecahkan masalah. Sehingga dengan demikian siswa akan memiliki pengetahuan dasar yang akan sangat menunjang keterampilanya dalam memecahkan masalah secara mandiri berdasarkan pengalaman yang telah dimilikinya. Video menyajikan obyek belajar secara konkret atau pesan pembelajaran secara realistik yang sangat baik untuk menambah pengalaman belajar siswa, serta penggunaan video pembelajaran membuat siswa lebih antusias dan termotivasi dalam memecahkan masalah (Apsari, Sudiarta, \& Suharta, 2018; Purwanti, 2015).

Model pembelajaran CPS yang dikombinasikan dengan video pembelajaran sangat mungkin untuk dapat diterapkan hal ini diperkuat oleh, Saminanto (2011) dalam penelitiannya diperoleh hasil bahwa pembelajaran matematika menggunakan model CPS dengan media video compact disk dapat meningkatkan pemahaman konsep, keaktifan, dan hasil belajar siswa. Purwanti (2015) menyatakan bahwa pengembangan media video pembelajaran matematika untuk penyajian data statistik dapat digunakan sebagai media pembelajaran.

Dalam penerapan model pembelajaran CPS berbantuan video pembelajaran aspek psikologi siswa tidak dapat diabaikan. Kerana dibutuhkan keinginan, kemauan, rasa tertarik, rasa butuh, dan rasa senang serta nyaman yang harus dimiliki siswa dalam proses pembelajaran. Salah satu aspek psikologis yang dimaksud adalah minat, seperti dalam penelitian Sardini, Buwono, S., \& Parijo (2013) diperoleh bahwa minat belajar siswa dapat mempengaruhi hasil belajarnya. Serta beberapa peneliti lainya yang menyatakan bahwa minat belajar siswa berpengaruh positif terhadap prestasi matematika siswa (Laksono, Ariyanti, \& Santoso, 2015; Sirait, 2016; Wilda, Salwah, \& Ekawati, 2016). Melihat hal tersebut minat belajar siswa tidak dapat diabaikan begitu saja dalam proses pembelajaran matematika. Minat belajar merupakan 
ketertarikan dan kecenderungan yang tetap untuk memperhatikan dan terlibat dalam aktivitas belajar karena menyadari pentingnya atau bernilainya hal yang dipelajari (Sardini, Buwono, \& Parijo, 2013). Jika dikaitkan dengan proses pembelajaran, ketika siswa telah berminat terhadap salah satu mata pelajaran maka siswa tersebut akan sangat tertarik untuk mempelajarinya, dan sangat mungkin untuk mengulang-ulang kegiatan belajar tersebut hingga benar-benar puas ditambah lagi dengan pemberian video pembelajaran yang akan sangat menunjang aktivitas siswa. Demikian hal nya dengan keterampilan siswa dalam memecahkan masalah yang merupakan fukos dalam pembelajaran CPS, minat akan mendorong siswa untuk terus berusaha mencari strategi dengan mengerahkan segala kemampuanya untuk menghasilkan ide-ide kreatif berdasarkan pengetahuan yang telah dimilikinya hingga menemukan solusi.

Berdasarkan hal yang telah diuraikan maka penelitian ini bertujuan untuk mengetahui kemampuan pemecahan masalah matematika dan minat belajar siswa pada materi aritmatika sosial yang mengikuti model pembelajaran CPS berbantuan video pembelajaran.

\section{Metode}

Penelitian ini merupakan penelitian kombinasi dengan menggunakan desain sequential explanatory. Data yang diambil baik data kuantitatif maupun kualitatif saling menunjang satu sama lain. Sampel sebanyak 54 siswa dari keseluruhan kelas VII SMPN 1 Lunyuk. Pengambilan sampel dilakukan dengan teknik cluster random sampling.

Secara kuantitatif, peneliti menggunakan tes untuk mengukur kemampuan siswa dalam memecahkan masalah matematika. Sementara itu, non-tes digunakan untuk mengumpulkan data kualitatif melalui wawancara, dan kuisioner. Untuk mendapatkan data yang valid dibutuhkan instrumen yang baik sehingga keandalan penelitian yang dihasilkan baik. Sebelum instrumen digunakan, terlebih dahulu harus diuji agar memenuhi tiga spesifikasi, yaitu (1) validitas instrumen dengan memasukan konten menggunakan rumus Gregory yang telah diuji sebelumnya oleh ahli, (2) validitas item dilakukan dengan langsung menguji coba instrumen yang dihitung menggunakan rumus product moment, (3) uji reliabilitas atau keandalan instrumen dihitung dengan rumus Alpha Cronbach.

Analisis data kuantitatif menggunakan uji asumsi terlebih dahulu yang yang terdiri dari uji normalitas data yang dilakukan dengan uji Kolmogorov Smirnov dan uji homogenitas varians dengan menggunakan uji Levene. 
Setelah data dinyatakan berdistribusi normal dan varians datanya homogen maka dilajutkan dengan uji hipotesis menggunakan uji-t. Kriteria signifikansi dilakukan dengan membandingkan hasil untuk menghitung t ( $\mathrm{t}$ hitung) pada $\mathrm{t}$ tabel ( $\mathrm{t}$-tab) dengan tingkat signifikansi 5\%. Jika t-hitung $>\mathrm{t}$ tab, maka dapat diartikan signifikan dan jika t-hitung $\leq \mathrm{t}$-tab, maka dapat diartikan tidak signifikan.

Aktivitas dalam analisis data kualitatif dilakukan secara interaktif dan berlangsung secara terus menerus sampai tuntas, hingga datanya telah jenuh jenuh. Aktivitas dalam analisis data kualitatif dilakukan dengan mereduksi data, menyajikan data, dan memverifikasi data.

\section{Hasil dan Pembahasan}

Data hasil kemampuan siswa dalam memecahakan masalah matematika secara umum dapat dilihat pada Tabel 1.

Tabel 1. Skor Tes Kemampuan Pemecahan Masalah

\begin{tabular}{ccc}
\hline Variabel & \multicolumn{2}{c}{ Post-Test } \\
& Kelompok Eksperimen & Kelompok Kontrol \\
\hline Banyak Siswa & 27 & 27 \\
Rata-rata & 76,26 & 65,11 \\
Standar Deviasi & 11,24 & 12,22 \\
\hline
\end{tabular}

Tabel 1 menunjukan bahwa skor rata-rata kemampuan siswa dalam memecahkan masalah matematika pada kelas eksperimen secara keseluruhan lebih tinggi dibandingkan dengan kelas konvensional. Namun untuk mengetahui apakah ada perbedaan kemampuan siswa dalam menyelesaikan masalah matematika pada kelompok eksperimen dan kontrol, perlu dilakukan uji hipotesis. Sebelum melakukan uji hipotesis terlebih dahulu dilakukan uji normalitas sebaran data (uji kolmogorov Smirnov) dan homogenitas varians (uji levene) dari hasil tes kemampuan siswa dalam menyelesaikan soal matematika. Hasil menunjukan bahwa kelompok data hasil tes kemampuan pemecahan masalah matematika siswa berdistribusi normal dan homogen. Langkah selajutnya adalah melakukan uji hipotesis dengan uji-t.

Berdasarkan hasil uji-t yang dilakukan pada hipotesis pertama menunjukkan bahwa nilai t-hitung $=3,489$ dan nilai t-tabel pada taraf signifikansi 0,05 dengan derajat kebebasan 52 adalah 1,674. Apabila dibandingkan, nilai thitung lebih dari nilai ttabel. Dengan demikian $\mathrm{H}_{0}$ ditolak dan $\mathrm{H}_{a}$ diterima. Jadi dapat disimpulkan bahwa kemampuan pemecahan masalah matematika 
siswa yang mengikuti model CPS berbantuan video pembelajaran lebih baik daripada siswa yang telah mengikuti pembelajaran konvensional.

Model pembelajaran yang diterapkan pada kelas eksperimen mendorong siswa untuk lebih aktif dan kreatif dalam memecahkan masalah. Dimana siswa diwajibkan mampu mengidentifikasi dan memahami masalah dalam merancang dan menentukan strategi penyelesaianya. Ini membuat siswa berpikir dengan memaksimalkan kemapuan yang dimiliki untuk menghasilkan ide-ide kratifnya yang kemudian dibahas dalam diskusi kelompok dalam memilih dan menentukan strategi yang mungkin untuk diterapkan. Karena kemampuan pemecahan masalah matematis dapat berkembang apabila adanya interaktif atau bertukar pendapat dalam menyelesaikan soal pemecahan masalah (Rostika \& Junita, 2017). Walaupun, penelitian Ningrum, Purnami, \& Widodo (2017) menjelaskan bahwa tidak terdapat perbedaan kemampuan pemecahan masalah jika diajarkan dengan model TAI maupun dengan pembelajaran langsung. Namun, beberapa penelitian yang menyatakan bahwa model CPS dapat meningkatkan aktivitas belajar siswa dan hasil belajarnya (Purwati, 2015; Tia, 2014; Sakaningsih, Asri, Negara, \& Ke, 2014).

Hasil uji-t yang dilakukan pada hipotesis kedua menunjukkan bahwa nilai thitung sebesar 2,268 dan nilai t-tabel pada taraf signifikansi 0,05 dengan derajat kebebasan 25 adalah 1,708. Apabila dibandingkan, nilai thitung lebih dari nilai ttabel. Dengan demikian Ho ditolak dan Ha diterima. Jadi dapat disimpulkan bahwa pada kelompok siswa yang memiliki minat belajar yang lebih tinggi, data kemampuan pemecahan masalah matematika siswa yang mengikuti model pembelajaran CPS berbantuan video pembelajaran lebih baik daripada siswa yang mengikuti pembelajaran konvensional.

Ini terjadi karena dalam proses pembelajaran dibutuhkan rasa tertarik serta nyaman hingga menumbuhkan kepuasan tersendiri dalam belajar. Siswa yang mememiliki minat belajar yang lebih tinggi biasanya cenderung lebih aktif dan antusias untuk berusaha memecahkan masalah. Hasil yang sama juga ditemukan oleh beberapa penelitian yang menyatakan bahwa minat belajar berpengaruh positif terhadap hasil belajar matematika siswa (Laksono, Ariyani, \& Santoso, 2015; Sirait, 2016; Wilda, Salwah, \& Ekawati, 2016).

Hasil uji-t yang dilakukan pada hipotesis ketiga menunjukkan bahwa nilai thitung sebesar 2,224 dan nilai ttabel pada taraf signifikansi 0,05 dengan derajat kebebasan 25 adalah 1,708. Apabila dibandingkan, nilai thitung lebih 
dari nilai t-tabel. Dengan demikian $\mathrm{H}_{0}$ ditolak dan Ha diterima. Jadi dapat disimpulkan bahwa pada kelompok siswa yang memiliki minat belajar yang lebih rendah, data kemampuan pemecahan masalah matematika siswa yang mengikuti model pembelajaran CPS berbantuan video pembelajaran lebih baik daripada siswa yang mengikuti pembelajaran konvensional.

Siswa yang memiliki minat belajar yang lebih rendah cenderung lebih sulit untuk memahami permasalahan matematika yang diberikan. Hal ini sangat berdampak pada kesalahan-kesalahan yang dilakukan baik dalam memodelkan soal maupun menentukan strategi penyelesaianya. Namun pada kelas eksperimen siswa dibentuk dalam beberapa kelompok dan disajikan masalah dimulai dari yang paling sederhana dan ditambah lagi dengan pemberian video sebagai pengetahuan awal membuat siswa setidaknya memiliki gambaran tentang materi yang akan dipelajari serta memiliki landasan dasar berpikir tentang strategi yang akan diterapkan untuk mencari solusi dari masalah yang diberikan. Selain itu juga guru mewajibkan siswa yang sudah paham untuk membantu membimbing dan mencoba menjelaskan bagian yang belum dipahami, kerana diakhir pertemuan salah satu perwakilan kelompok akan ditujuk secara acak sehingga mau tidak mau setiap anggota harus paham. Walaupun belum tercapai secara maksimal kemampuan pemecahan masalah matematika siswa yang memiliki minat belajar yang lebih rendah pada kelas eksperimen lebih baik daripada kelas kontrol.

Berdasarkan hasil observasi aktivitas pembelajaran yang dilakukan pada kelas eksperimen ditemukan bahwa proses pembelajaran yang dilakukan berjalan dengan kondusif dan siswa antusias mengikuti proses pembelajaran. Siswa terlihat aktif bertanya maupun mengemukakan pendapatnya pada saat diskusi. ketika proses pemecahan masalah banyak yang sudah mampu memodelkan permasalahan secara mandiri yang diberikan meski ada beberapa yang masih kesulitan dalam merancang strategi penyelesaianya. Secara umum aktivitas pemecahan masalah yang dilakukapan pada setiap pertemuanya berjalan dengan baik.

Dari hasil wawancara pada kelas eksperimen diketahui siswa sangat senang dengan pembelajaran yang diterapkan. Terlebih lagi dengan adanya video yang menurut mereka sangat menarik dan mudah untuk dipahami. Meski beberapa siswa menyatakan bahwa video yang disajikan sedikit berbeda dengan permasalahan di LPM (lembar pemecahan masalah) tetapi sangat membantu karena setidaknya tahu apa yang harus dilakukan terlebih dahulu. Mereka juga antusias bertanya karena sebagian siswa mengaku 
mengetahui secara garis besar materi yang akan dipelajari (setengah paham). Secara umum menurut mereka proses pembelajaran yang diterapkan sangat menarik dan diakui juga bahwa mereka merasa nyaman dan tidak canggung ketika berdiskusi.

Dari hasil angket respons siswa pada kelas eksperimen proses pembelajaran yang dilakukan membuat mereka lebih termotivasi untuk memaksimalkan kemampuanya. Mereka juga merasa lebih mudah memahami materi pelajaran dan merancang strategi penyelesaian masalah meskipun masalah yang ada di LPM sedikit berbeda dengan yang ada di video. Video pembelajaran yang diberikan juga menurut meraka sangat menarik (belum pernah diberikan video pembelajaran) dan dapat dipelajari sendiri dirumah. Dikusi kelompok yang dilakukan sangat menunjang kemapuan mereka karena beberapa hal yang tidak bisa ditanyakan kepada guru bisa ditanyakan kepada temanya.

Setelah dilakukan verifikasi dari data kualitatif yang dikumpulkan, diperoleh kesimpulan bahwa model pembelajaran CPS berbantuan video pembelajaran yang diterapkan pada kelas eksperimen dapat membuat siswa; 1) menjadi lebih semangat dan antusias dalam mengikuti proses pembelajaran; 2) lebih mudah memahami materi dan memecahkan masalah karena memiliki pengetahuan awal; 3) mampu memaksimalkan kreativitas berpikirnya melalui diskusi; 4) lebih mandiri dalam belajar dan mempersiapkan diri untuk menyelesaikan permasalahan yang akan diberikan. Secara umum dapat dikatakan bahwa pembelajaran yang diterapkan pada kelas ekperimen berkontribusi positif terhadap kemampuan siswa dalam memecahkan masalah matematika.

\section{Simpulan}

Berdasarkan penelitian yang dilakukan, diperoleh beberapa kesimpulan yaitu kemampuan pemecahan masalah matematika siswa yang pebelajarannya menggunakan model CPS berbantuan video pembelajaran lebih baik daripada siswa yang mengikuti pembelajaran konvensional; pada kelompok siswa yang memiliki minat belajar yang lebih tinggi dan yang lebih rendah, kemampuan pemecahan masalah matematika siswa yang mengikuti model pembelajaran CPS berbantuan video pembelajaran lebih baik daripada siswa yang mengikuti pembelajaran konvensional; model pembelajaran CPS berbantuan video pembelajaran berkontribusi positif terhadap kemampuan pemecahan masalah matematika pada materi aritmatika sosial. 


\section{Daftar Pustaka}

Aljaberi, N. M., \& Gheith, E. (2016). Pre-Service Class Teacher'Ability in Solving Mathematical Problems and Skills in Solving Daily Problems. Higher Education Studies, 6(3), 32-47.

Apsari, D.S., Sudiarta, I G.P., \& Suharta, I G.P. (2018). The Effect of Blended Learning Using Tutorial Videon Towards Problem Solving Ability Reviewed of Students' Logical intelligence. International Journal of Science and Engineering Investigations, 7(1), 22518843.

Febriatina, D. (2017). Perbandingan Model Pembelajaran Creative Problem Solving (CPS) dan Problem Based Learning (PBL) Untuk Meningkatkan Kemampuan Berfikir Kritis denganMemperhatikan Minat Belajar Siswa pada Mata Pelajaran Sosiologi Kelas X SMA Negeri 1 Seputih Mataram. Tesis. FKIP. Bandar Lampung: Universitas Lampung.

Herlambang. (2013). Analisis Kemampuan Pemecahan Masalah Matematika Kelas VII-A SMP Negeri 1 Kepahingan Tentang Bangun Datar Ditinjau Dari Teori Van Hiele. Tesis. Pendidikan Matematika. FKIP. Universitas Bengkulu.

Huda, M. (2013). Model-model Pengajaran dan Pembelajaran. Yogyakarta: Pustaka Pelajar.

Laksono, Y. S., Ariyanti, G., \& Santoso, F. G. I. (2016). Hubungan Minat Belajar Siswa terhadap Prestasi Belajar Matematika Siswa dalam Pembelajaran Kooperatif Tipe STAD Menggunakan Komik. Jurnal Edukasi Matematika dan Sains, 1(2), 60-64.

$\mathrm{Ng}$, P. T. (2017). Learning from Singapore: The power of paradoxes. Taylor \& Francis.

Ningrum, E. K., Purnami, A. S., \& Widodo, S. A. (2017). Eksperimentasi Team Accelerated Instruction terhadap Kemampuan Pemecahan Masalah Matematika Ditinjau dari Kemampuan Awal Siswa. JNPM (Jurnal Nasional Pendidikan Matematika), 1(2), 218-227.

OECD. (2016). Assesment Framework-Mathematics, Reading, Science and problem Solving Knowledge and Skills. Paris: OECD.

Pujiadi. (2008). Pengaruh Model Pembelajaran Matematika Creative Problem Solving (CPS) Berbantuan CD Interaktif terhadap Kemampuan Pemecahan Masalah pada Siswa SMA Kelas X. Tesis. Program Pasca Sarjana Program Studi Pendidikan Matematika. Semarang: UNNESA.

Purwanti, B. (2015). Pengembangan Media Video Pembelajaran Matematika dengan Model ASSURE. Jurnal Kebijakan dan Pengembangan Pendidikan, 3(1), 1-12.

Purwati. (2015). Efektifitas Pendekatan Creative Problem Solving Terhadap Kemampuan Pemecahan Masalah Matematika pada Siswa SMA. Jurnal Ilmiah Edukasi Matematika (JIEM), 1(1), 1-10.

Rofiqoh, Z. (2015). Analisis Kemampuan Pemecahan Masalah Matematika Siswa Kelas X Dalam Pembelajaran Discovery Learning Berdasarkan Gaya Belajar Siswa. Doctoral dissertation, Universitas Negeri Semarang.

Rostika, D., \& Junita, H. (2017). Peningkatan Kemampuan Pemecahan Masalah Siswa SD Dalam Pembelajaran Matematika Dengan Model Diskursus Multy Representation (DMR). Eduhumaniora: Jurnal Pendidikan Dasar, 9(1), 35-46.

Sakaningsih, N. M., Asri, I. G. A. S., Negara, I. G. A. O., \& Ke, S. P. M. (2014). Model Pembelajaran Creative Problem Solving Berbasis Reinforcement Berpengaruh Terhadap Hasil Belajar PKN Siswa Kelas V Sd N 18 Dangin Puri. Jurnal MIMBAR PGSD Undiksha, 2(1), 1-11.

Saminanto. (2011). Model Pembelajaran Creative Problem Solving dengan Video Compact Disk Untuk Mencapai KD dalam Pembelajaran Matematika di MTs. Jurnal Phenomenon 1(1), $1-10$. 
Sardini, S., Buwono, S., \& Parijo. (2013). Pengaruh Minat Belajar Terhadap Hasil Belajar Pelajaran Ekonomi Siswa Kelas XI IPS MAN Pontianak. Jurnal Pendidikan dan Pembelajaran Khatulistiwa, 2(7), 1-17.

Sirait, E. D. (2016). Pengaruh Minat Belajar terhadap Prestasi Belajar Matematika. Formatif: Jurnal Ilmiah Pendidikan MIPA, 6(1), 35-43.

Susanto, A., (2013). Teori Belajar \& Pembelajaran di Sekolah Dasar. Jakarta: Kencana Prenadamedia Group.

Tia, F. J., Dalifa, D., \& Noperman, F. (2014). Penerapan Model Creative Problem Solving (CPS) Dikolaborasikan dengan Model Cooperative Tipe Team Game Turnament (TGT) Untuk Meningkatkan Aktivitas Dan Hasil Belajar IPA. Tesis. Universitas Bengkulu.

Wilda, W., Salwah, S., \& Ekawati, S. (2016). Pengaruh Kreativitas dan Minat Belajar terhadap Hasil Belajar Matematika Siswa. Pedagogy: Jurnal Pendidikan Matematika, 2(1), 134-160. 